\title{
OF POSITIVISM AND THE HISTORY OF ECONOMIC THOUGHT
}

\author{
BY BRUCE CALDWELL
}

CHOPE Working Paper No. 2012-09

November 2012

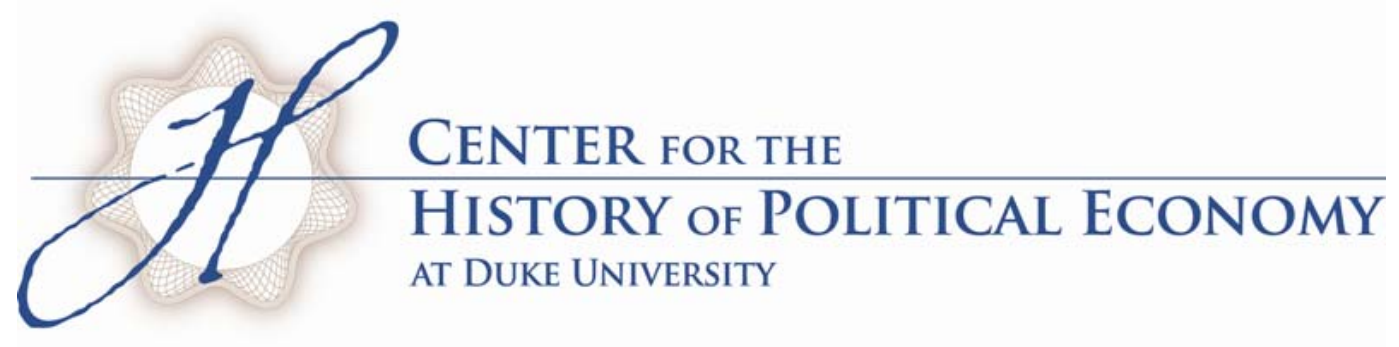




\title{
Of Positivism and the History of Economic Thought*
}

\author{
Bruce Caldwell - Duke University
}

SEA Presidential Address

November 2012

* For their helpful comments I would like to thank Karen Vaughn, participants at a session at the 2012 History of Economics Society meetings, and members of the History of Political Economy workshop at Duke University. Any errors of fact, interpretation, judgment, or discretion are mine. 


\begin{abstract}
The rhetoric of positivism had a profound effect on the worldview and practice of economists in the middle of the last century. Though this influence has greatly diminished, it still may be found in the attitude of many economists towards the history of their discipline. This paper traces the effects of positivism in economics, then argues that the history of economics is a critical component of both the undergraduate teaching and the graduate training of economists, and that as such, it should be reintroduced into the economics curriculum. It concludes by documenting some recent hopeful signs of change.
\end{abstract}

Keywords: positivism, history of economic thought, history of economics, economic methodology, undergraduate education, graduate education, Hayek

JEL Codes: A11, A12; A22, A23, B0, B1, B2, B3, B4 


\section{Of Positivism and the History of Economic Thought}

You will never want booksellers, while there are buyers of books: But there may frequently be

readers where there are no authors. David Hume, "Of the Rise and Progress of the Arts and

Sciences," [1742] 1987, p. 113.

...there has been history, but there is no longer any. Karl Marx, The Poverty of Philosophy, [1847]

n.d., p. 121.

I am an historian of economic thought, and those who are familiar with my research will

know me as a Hayek scholar, but my earliest work was in the area of economic methodology, a

subfield that operates in the interstices of philosophy and economics. One of my goals in this

paper is to make the intellectual historian's point that ideas matter, that they have

consequences for how we see the world and organize our practice. ${ }^{1}$ The specific case I will

examine will draw on my early work on methodology. I will show the effect that various

philosophical doctrines, loosely known as positivism, had on the worldview and practice of

economists in the middle of the last century. It turns out that the rhetoric of positivism had a

\footnotetext{
${ }^{1}$ This complements but goes beyond Keynes' famous peroration for The General Theory (Keynes 1936, p. 383) regarding the influence of the ideas of past economists on current policy: “...the ideas of economists and political philosophers, both when they are right and when they are wrong, are more powerful than is commonly understood. Indeed the world is ruled by little else. Practical men, who believe themselves to be quite exempt from any intellectual influences, are usually the slaves of some defunct economist. Madmen in authority, who hear voices in the air, are distilling their frenzy from some academic scribbler of a few years back. I am sure that the power of vested interests is vastly exaggerated compared with the gradual encroachment of ideas." But ideas do not only affect policy-makers, they affect the economists whose ideas affect policy-makers.
} 
real effect on economics and other social sciences, even as it was dying out as a force within the philosophy of science. I am happy to report that it has now mostly died out in economics, as well.

The "mostly" is important though, for one area where it continues to have influence is in the way that many economists view the history of their discipline. Throughout the second half of the twentieth century interest in the study of the history of economic thought experienced a rather steep decline (see, e.g., Weintraub, ed. 2002). Though lately this shows some signs of turning around, the situation is still sufficiently worrisome that I will spend some of my space here making the case that the study of the history of economics has an important role to play in the training of economists. In the process I hope to seduce (intellectually, of course) some of the younger scholars among my readers, and perhaps also some older ones, into reconsidering the history of thought as a teaching and research field.

\section{The Legacy of Positivism}

I will begin with a little personal history, to give you an idea of my own path to the study of history and methodology. I attended undergraduate and graduate school in the 1970s, which were turbulent times politically, with the end of the Viet Nam war, Watergate, and a Middle Eastern conflict that ended in an oil embargo, but also economically, with ever- 
worsening stagflation being met with such devices as wage-price controls, WIN buttons, malaise speeches, and stop-go policy. It was a time when certain well-established paradigms within economics were being challenged, most evidently the notion of a stable Phillips Curve trade-off between inflation and unemployment. New groups that challenged the mainstream, like the Union for Radical Political Economy, were emerging, as were new publishing outlets, like the Journal of Post-Keynesian Economics. I well remember my first ASSA meeting, and seeing protesters following Milton Friedman around and chanting outside the doors of his sessions.

Strangely, though, what we were learning in graduate school had nothing, zero, to do with any of this: it was as if the outside world, and the challenges to our understanding of it, did not exist. Once, outside of class, I asked my macroeconomics teacher, who had been filling the blackboard with growth models all semester, if he might consider talking in class about whether the modeling strategy that had been used by Nicholas Kaldor reflected in any way Kaldor's radical politics. "That's sociology!" he snorted and walked away, assuming, I suppose, that simply saying that was argument enough. I would be interested in whether any parts of this story might resonate with recently trained junior faculty, given the recent economic 
unpleasantness and the frequently encountered claim from outside the discipline that our

profession if not culpable has generally been oblivious to it. ${ }^{2}$

I also found it troubling that there were a number of areas within economics that I

personally found interesting, areas that are now well established, that were either ignored or

treated dismissively, and often on the grounds that they were in some way "unscientific."

Given its current ubiquity, younger faculty will be surprised to hear that game theory was one

of these. Another was the public choice theory of the Virginia School; indeed, though I was

educated in the south I never heard anything about it in any of my classes. ${ }^{3}$ Though

experimental economics was occasionally published in mainstream journals, its status too was

highly ambiguous. Another area that was derogated by some of my professors was the history

of economic thought, more about which soon. ${ }^{4}$

\footnotetext{
${ }^{2}$ There is, of course, a larger point to recalling this personal history. Interest in both methodology and the history of our discipline tends to grow in times of crisis. It happened in the 1930s, and again in the 1970s, and is happening again today.

${ }^{3}$ The silence may have been for ideological rather than "scientific" reasons, but the arguments are not unconnected. For example, in the classes I took Friedman's work was often criticized as "ideological," which meant "unscientific" because it violated the "science is value-free" norm. This is ironic, given that Friedman famously insisted that economists should focus on positive questions, and thought that the normative ones would take care of themselves; see Friedman 1953. The Virginia School suffered similar treatment in its early days, as James Buchanan (1988) recounts.

${ }^{4}$ One of the most back-handed compliments I ever received was from a professor who had taught me and who asked, "What's a smart person like you doing choosing history of thought as your major field?" This paled in comparison, though, to the remark by the recruiting chair of a major mid-western university who, sitting in the bar amid a number of junior job candidates, said, upon hearing my field: "Some say history of economic thought is a dying field. I disagree. I say it is a dead field." I must confess that this cretinous joke at the expense of an aspiring
} 
As my graduate education proceeded I wanted to know why certain areas that I found

interesting were undervalued by the profession, and how economists determined what was

scientific and what was not. In a course on economic methodology (yes, a graduate course on

methodology) at the University of North Carolina I discovered the philosophy of science, which I

thought might provide, if not the answer, at least some insight. In my rather unconventional

dissertation I first surveyed $20^{\text {th }}$ century philosophy of science, then used it to assess the

writings of economists like Milton Friedman, Paul Samuelson, Terence Hutchison, Fritz

Machlup, and others, on the proper way to do economics (Caldwell [1982] 1994).

My results were strange. In explicating their methods, to the extent that economists

made reference to the philosophy of science at all, it was usually to some variant of positivism, ${ }^{5}$

a doctrine that was created with the natural rather than social sciences in mind. Positivism

attempted to lay out the practices and procedures that all "real sciences" followed. It provided

models of what constituted legitimate scientific explanations, it offered criteria by which

junior academic by a person in power, in public no less, simply steeled my resolve to pursue the study of the history of ideas.

${ }^{5}$ For those who know the methodological literature, I should note that I am using "positivism" very loosely to refer to a broad set of doctrines, not just the logical positivism of the Vienna Circle or the logical empiricism of the 1950s and 1960s, but also to such ideas a operationalism and instrumentalism, the latter two of which has clear analogues in the methodological writings of certain economists. For more on these distinctions see Caldwell [1982] 1994. 
competing theories could be appraised (chief among these predictive adequacy), it provided a vision of how a scientific field normally progressed.

What was strange was that positivism was no longer considered a viable position within philosophy. It had died out chiefly because it became evident that no science had ever followed its strictures; it collapsed from within. Yet in many of the social sciences practitioners kept referring to positivist ideas (albeit typically without any direct knowledge of their origins), one suspects because people working in these fields have always found it necessary to defend the proposition that the social sciences are, really truly are, scientific. In short, in describing and defending their practices, economists had been borrowing, often badly, from an increasingly suspect because unworkable philosophical position.

It gets worse. Economists were not following the strictures of positivism, because no science can. But positivist rhetoric was alive and well, for it was the rhetoric of hard science. And it had consequences, because the rhetoric was being used to justify certain theory choices, some that economists might judge, in retrospect, as either good or bad. For example, the notion that science only makes reference to observables was why Paul Samuelson thought it 
necessary to develop revealed preference theory. ${ }^{6}$ The quest for ever more precise predictions, another hallmark of positivism, delayed the acceptance of game theory, because one could use game theory only to describe, not to predict, the moves of, say, competing oligopolists. ${ }^{7}$

There is plentiful evidence, however, that economists were not universally following the official rhetoric. General equilibrium theory was a dominant research program in the middle of the last century. Scores of explorations of the existence, stability, and determinateness of equilibrium were published, and this at the very time that positivist rhetoric was at its apogee. Yet most would agree ${ }^{8}$ with the observation of that great historian of economics Mark Blaug that general equilibrium theory is empirically empty, which is from a positivist's point of view is grounds for it being considered pseudo-scientific.

A second example is experimental economics. Early experimentalists probably came closer than any other economists to transferring certain of the practices of the physical and

\footnotetext{
${ }^{6}$ In this Samuelson was apparently influenced by Percy Bridgman, a physics professor and eventual Nobel laureate at Harvard who in his 1927 book The Logic of Modern Physics developed operationalism, the view that a phenomenon is defined through the operations by which it is measured.

${ }^{7}$ My graduate microeconomics professor taught a section on game theory, but he also let us know that he thought that it was not a very important a tool because of its limited ability to generate falsifiable predictions. Franklin Fisher 1989 argued that it was necessary to expand the type of theorizing that was deemed acceptable for game theory to come into its own; specifically, a move away from "generalizing" and toward "exemplifying" theorizing had to occur. As Fisher notes, exemplifying theory is more difficult to falsify, which is a positivist no-no. For more on this see Caldwell 2004, pp. 393-95.

${ }^{8}$ See Blaug [1980] 1992, chapter 8. My caveat "most" is in deference to is the interpretation of my colleague Roy Weintraub, who characterized GE theory as the "hard core" of a Lakatosian research program, for which testing took place in the "protective belt" of applied fields. See Weintraub 1988.
} 
laboratory sciences, as well as the accompanying rhetoric, into economics. ${ }^{9}$ They did so selfconsciously; it is not for nothing that they named their professional association not the Experimental Economics Association, but the Economic Science Association. Yet for decades mainstream economists resisted their entry into the club, probably for a variety of reasons that had nothing to do with any philosophical reconstruction of appropriate scientific practice. ${ }^{10}$

We can finally mention that Samuelson himself, after showing his readers that revealed preference theory allows one operationally to define preference without making reference to unobservables like "utility," and thereby to test the theory of consumer behavior, concluded his discussion with the following frank admission: ...the pure theory of consumer's behavior, when its empirical meaning is finally distilled from it, turns out to be one simple hypothesis on price and quantity behavior. ...I wonder how much economic theory would be changed if either of the two conditions

\footnotetext{
${ }^{9}$ In a "witness seminar" that brought some of the leading experimentalists together to reflect on the early days of the Association, it is clear from a number of the exchanges that though many of them embraced the rhetoric of testing and falsification, the actual practice was much richer. The revelation that the framing of the experiment (e.g., whether the initial distribution in the dictator game is viewed by subjects as "fair" or "unfair") has a discernible impact on its outcome is a case in point. There are no simple tests, no simple falsifications of a theory, and always, context matters. See Maas and Svorencik, 2012.

${ }^{10}$ The history has yet to be written, but presumably part of the problem was the century-long refusal of mainstream economists to incorporate contemporaneous trends in psychology into their theories, and part of it may have been the challenge that one faces in interpreting some its results. On the one hand, subjective utility theory seemed systematically falsified by many types of tests; on the other, some experimentalists had shown that female psychotics, and even rats, have downward sloping demand curves. What conclusion is one to draw from such evidence? None seemed particularly favorable to the economic theory of the day.
} 
above were found to be empirically untrue. I suspect, very little (Samuelson [1947]

1965, p. 117).

In short, the actual history of economics, like that of every science, is much messier,

idiosyncratic, and, frankly, interesting, than any image of science portrayed within the

philosophy of science.

All of this would be mildly amusing were it not for the impact of the acceptance of the positivist vision of science on my own chosen field of study, the history of economic thought. A bedrock belief of positivism is that all real sciences are cumulatively progressive, that slowly but surely within science errors are discarded and a widely accepted body of knowledge is created. This view leads naturally to the belief that an understanding of the history of a discipline is simply irrelevant for a scientist, because all knowledge is contained in the most recent working papers. History is for antiquarians and hobbyists, not for real scientists.

If the alternative accounts of how science actually is pursued that emerged in the wake of positivism's demise are correct, however, the idea that science develops linearly and progressively is simply false. Historians and philosophers of science like Thomas Kuhn and Imre Lakatos offered the initial alternatives to the positivist view, in the process demonstrating that the history of the natural sciences is a much messier affair than previously thought, that no 
hard and fast criteria for theory choice exist, that scientific disciplines change emphases and approaches for a host of reasons both internal and external that require examination and explication. ${ }^{11}$ Their pioneering work was later extended by sociologists, historians, and science studies specialists, who though differing from one another in approach all demonstrated, through numerous close examinations of practice, the contingent nature of scientific change. ${ }^{12}$

Just to make sure that I am not misunderstood: All of this is not a denial that science exists. It is just that our image of what constitutes science has changed. And crucially, if the new account is correct, knowing the history of a field becomes much more important for its practitioners. Just as context matters in providing instructions to subjects in an experiment, it matters too in understanding one's own disciplinary practice.

If we fast forward to the present, it is clear that the legacy of positivism has in most cases disappeared in economics. Compared to forty years ago, the pluralism we see in the practice of economics is everywhere evident. We see this in the rapid development of areas like game theory, behavioral, experimental, and neuroeconomics, public choice theory, and the new institutional economics. We see decision theorists who eschew axiomatic approaches in

\footnotetext{
${ }^{11}$ The classic citations are Kuhn [1962] 1970 and Lakatos 1970 and 1971. For early applications of these ideas to economics, see Latsis, ed. 1976.

${ }^{12}$ The new landscape is well-captured in Hands 2001 on the variety of approaches that have replaced the normative approach of the positivists ("normative" because it sought to articulate the way that science was supposed to be done), aptly titled Reflection without Rules.
} 
analyzing choice. We see artificial society modeling, agent-based computational economics,

and other attempts to represent complex systems. We see field experiments, natural

experiments, and randomized control trials. We see theorists hypothesizing about multiple

selves, and empirical economists adopting multiple standards for hypothesis testing. In almost

every way, the practice of economics has broken out of the chains imposed by the positivist

view of what constitutes "proper science."

The one place it has had lingering effects is in the treatment of the history of economics,

which as a consequence has become absent in many places from the economics curriculum. As

you might expect, I find this at once appalling and curious, the former for obvious reasons and

the latter because it is always strange to find that other people do not share one's passion. But

happily, this has been changing of late, as I will demonstrate at the end of the paper. But now,

in the event that any readers are still operating under positivist prejudices, I will lay out a few

arguments for why history of economics still belongs in the economics curriculum. ${ }^{13}$

The Liberal Education of Economists

Let me focus first on undergraduate education. I can attest from decades of personal

experience and from anecdotal evidence from others that, when it is offered, undergraduate

\footnotetext{
${ }^{13}$ In this I am joining a distinguished (and far more eloquent and erudite) company; since the 1960s economists who have been interested in the history of the discipline have felt compelled to defend its study. See, e.g., Viner [1963] 1991, Boulding 1971, Vaughn 1993, O'Brien 2000, Blaug 2001, and Davis forthcoming.
} 
economics majors typically love the history of economic thought, and this for a number of reasons.

First, the history of economics deals with origin stories. Students who learn their economics from textbooks without the benefit of a history of thought course do not realize that the development of ideas always involves argumentation, debate, and criticism, things that disappears in textbook treatments. The actual history is often fascinating, as are the cast of characters involved.

Next, the history of economics provides a means, through the reading of original texts and related documents, of engaging with some of the greatest minds of our profession, debating the great questions: historian Brad Bateman has nicely described this aspect of a typical undergraduate course as "sitting on a log with Adam Smith" (Bateman 2002). In a history of economic thought class, you do not read some textbook writer on Smith. You read Smith's own words, words that a good teacher will place into context. I mention the importance of a good teacher. It is not easy to sit down and read a writer from another time period. But with help, a student's understanding of the world expands. This is why courses in the history of economics are so important. I will add that many of the authors were wonderful prose stylists, 
as a perusal of the first chapter of Smith's Theory of Moral Sentiments, or Marx and Engels'

Communist Manifesto, or any of Keynes' essays, reveals.

Speaking of writing, the history of economics course is ideal for developing what are

often called "critical thinking" skills, that is, writing and speaking effectively and persuasively

by composing well-supported arguments. In too many of their classes, undergraduate

economics majors passively listen to lectures, then hand in problem sets. I have had graduating

seniors at Duke University who struggled with their writing assignments, telling me that the last

time they had written anything was in a freshman seminar. ${ }^{14}$ We used to say that life is not a

multiple choice test; it is also not a problem set. The ubiquity of the "problem set approach" to

teaching, which not incidentally makes things much easier for instructors, particularly if they

have graduate students to do the grading, should be a scandal. That it is typically viewed as

"best practice" should be an indictment. ${ }^{15}$

One of the essential messages of any history of thought class is that one encounters,

over and over again through history, the same sets of ideas and concerns, though typically in

\footnotetext{
${ }^{14}$ To its credit the Duke Economics Department recently revamped its undergraduate curriculum to require that students take a mix of elective courses, some focusing on the application of the standard tools, others asking students to engage with ideas rather than with techniques.

${ }^{15}$ It might further be noted that once online education really takes off, as eventually it must, the "problem set approach" is custom made for it. This brings to mind Marx and Engels's assessment of the practices of the bourgeoisie in the Communist Manifesto: "What the bourgeoisie, therefore, produces, above all, is its own gravediggers" (Marx and Engels [1848] 1978, p. 483).
} 
new settings and perhaps in new wrappings. Milton Friedman once nicely put this as finding

"Old Wine in New Bottles" (Friedman 1991). This discovery produces both an appreciation for

the past and some humility concerning the "insights" of the present.

Another role of the historian of thought is to correct egregious errors of interpretation.

To say this is not to take an absolutist stance towards historical interpretation: Historians of

economics disagree all the time about interpretive matters. But often what passes as common

knowledge is not a matter of interpretation, but simply and demonstrably wrong. Indeed, one

of my students recently asked, somewhat plaintively, about halfway through the semester, "Are

we ever going to get to someone who actually thought what we thought he thought?" This

problem, by the way, will only get worse if historians disappear and the writing of our

discipline's history gets taken over by journalists, or by those with partisan axes to grind. ${ }^{16}$

Finally, the history of economic thought class is one of the only places in the

economics curriculum where students are exposed to alternatives to mainstream views.

\footnotetext{
${ }^{16}$ Without naming names, some recent histories of economics that were written by journalists contained numerous factual inaccuracies and interpretative leaps. An example of the partisan use of history that gets the relevant history wrong is provided by Nobel laureate Paul Krugman who, in arguing for a more robust Keynesian remedy to the recent downturn, wrote that, "Until the Great Depression, most economists clung to a vision of capitalism as a perfect or nearly perfect system" (Krugman 2009). This bald statement provoked considerable discussion and much criticism on the Societies for the History of Economics (SHOE) list-serv: see the entries in January 2007 https://listserv.yorku.ca/archives/shoe.html under "All pre-1936 economists were laissez faire." Krugman's claim is akin to one Keynes himself made, polemically, on the opening pages of The General Theory, where he boldly stated that his mainstream British predecessors (i.e., Ricardo, Mill, Marshall, Edgeworth, and Pigou) were all just "classical" economists (Keynes 1936, p. 3). It may be that Krugman simply took Keynes's selfpromotional polemics too seriously. For a debunking of many myths surrounding Kenyes, some perpetuated by proponents and others by opponents of (what they take to be) Keynes's message, see Bateman (2006).
} 
Where else in the economics curriculum will students actually read, not just Smith, Marshall, Knight, and Keynes, but Marx, Veblen, Schumpeter, Mises, and, dare I say it, Hayek?

The benefits of having been exposed to the history of economics described so far may be lumped under the broad category of becoming a more liberally educated person. It used to be taken as given that this was not a, but the, principal goal of an undergraduate education. Like teaching one's children good manners and hygiene, it was viewed as something that we, as educators, owed to our students. And I hope and suspect that many readers will agree.

Even those who do, however, may balk at the notion of including the history of economics and economic methodology in the training of graduate students, who require specialist training to become professional economists. So is there any room for the history of economics in the graduate curriculum? My answer, you will have guessed, is yes.

\section{Graduate Training in Economics}

The first argument is simple: if you accept the argument that I just made that the history of economic thought is an important part of an undergraduate education, the question then arises: Where will the next generation of teachers come from, if graduate training in the field disappears? To have one, you need at least some of the other. This does not mean that every graduate program in economics has to offer the field, of course. But there is certainly room for 
more than there is today. This is a niche market that currently is wide open and ready to be exploited; anyone familiar with the advantages conferred by specialization should take note.

A second argument concerns the dangers of presentism. Recall that the positivists believed that science progresses in a linear fashion, leading to a steady accumulation of true theories, and that later work showed this to be a myth. The way this myth shows up in graduate education is when students are trained - and indeed come to believe - that all relevant economics began about five years before they entered graduate school. This is a barrier to the advance in economic knowledge for at least three reasons.

First, ignorance of history is a barrier to the growth and accumulation of knowledge: students who learn economics via working papers, whose only knowledge of the history of the discipline is through occasional anecdotes or potted caricatures in textbooks written by faculty who are usually equally ill-acquainted with the past, are almost doomed to reinvent the wheel. Second, when apparently promising avenues of inquiry disappoint or research leads to dead ends, as so often happens in all sciences, the record of how we got to the impasse can provide a map back to paths not taken. Third, a knowledge of history may lead to the revival of an old idea as modeling techniques improve: for example, the Hayekian notion of the market as a 
competitive process was difficult to capture with theories that emphasized equilibrium, but

with recent advances theory it is again coming into its own. ${ }^{17}$

Students who know the history of economics are thus more aware that other options

are available and of which options they are. Furthermore, what may have seemed to be a

compelling move at one time may look quite different when conditions change. And to

understand that it was a contingent move in the first place, and not the very definition of good

economics for all time, is the beginning of true historical sensibility. ${ }^{18}$ Indeed, when one knows

more about the history of one's discipline whole new sets of questions and insights arise. Then

the idea that all that one needs to know about economics is contained in the latest working

paper can be seen for what it is: a simple (and simplistic) expression of scientistic prejudice.

Skeptics will reply that a knowledge of, say, the writings of Smith or Marx will not help

current graduate students. I disagree, but it should also be said that this objection reveals

ignorance of what most historians of economics today actually do. Simply put, much of the

\footnotetext{
${ }^{17}$ See, e.g., Frydman and Goldberg 2011 for examples of using insights from the past in developing models with contemporary relevance.

${ }^{18}$ A superb example of the contingency of history is provided in Roy Weintraub and Ted Gayer's compelling description of the idiosyncratic referee process that led to the publication of one of the most influential economic papers of the $20^{\text {th }}$ century, Kenneth Arrow and Gerard Debreu's 1954 "On the Existence of an Equilibrium for a Competitive Economy." Only a handful of people had the mathematical skills to referee the paper; a mathematician who refereed it called for its rejection, and sent a letter of protest when it was published; the authors ignored virtually all of the suggested revisions offered by the associate editor of Econometrica, Nicholas Georgescu-Roegen, the only economist who appears to have read the paper carefully; and for all that the paper became an overnight classic. For twenty years the profession was enthralled with questions relating to the program, and then, nearly overnight again, interest waned. See Weintraub and Gayer, in Weintraub 2002, chapter 6. Try fitting that story into a positivist model of proper scientific procedure!
} 
research done by Fellows and faculty members at the Center for the History of Political

Economy at Duke involves examining the development of economics in the $20^{\text {th }}$ century.

Let me quickly provide some examples. Every April the Center runs a history of

economics conference; recent and forthcoming themes have included the history of

econometrics and the role of MIT in the transformation of American economics. Two years ago

Paul Samuelson's papers were deposited at Duke. The response by scholars has been huge,

indeed, the reading room has been jokingly dubbed the "Paul Samuelson reading room" by the

archivists. Another project undertaken by a Fellow of the Center and others was a "witness

seminar" that brought together some of the major figures in the experimental economics

movement to discuss their memories of the beginnings of the movement. ${ }^{19}$ Because memories

are often faulty, this material will ultimately be combined with archival evidence to construct a

narrative that portrays the birth of the new sub-field. In my own research area, recent archival

scholarship has revealed F. A. Hayek's until now unappreciated role in the foundation of the

Chicago School (see, e.g., Van Horn and Mirowski 2009, Caldwell 2011), and I also recently

discovered the text of a series of lectures he delivered in the spring of 1961 at the University of

Virginia that sheds considerable new light on his views on the methodological limitations of

\footnotetext{
${ }^{19}$ The seminar took place in May 2010, and final corrections to the transcript of the discussions are now being
} completed; see Maas and Svorencik, 2012. 
economics. The history of the development of economics in the twentieth century has finally begun to be more fully written, and there are many, many areas that await interested scholars to explore.

Another benefit of including the history of economics in graduate training is to help students recognize presuppositions that we, as members of a discipline, inevitably make. Our History of Political Economy workshop at Duke often draws scholars from other departments, among them philosophy, sociology, political science, and English. I also have attended a number of Liberty Fund events where economists were in a minority. At both types of events I am reminded over and over again that communication across fields is often very difficult, simply due to the variety of unstated assumptions that people bring from their particular disciplinary backgrounds, and to the difficulty of being aware of and articulating to others, one's own assumptions. Different disciplines read texts differently, and bring different sensibilities to what they read. This is because disciplinary specialization is a form of brain-washing: this is how you are to look at problem $x$ if you are an economist, or a political scientist, or a sociologist.

Such specialization has obvious benefits but also costs, and for economists, studying the history of ideas can provide at least partial remediation. What one discovers when one studies 
history is that, just like the sociologists or political scientists at my workshop, ${ }^{20}$ economists in the past looked at the world differently, they asked different questions, not least because it was a different world that they were looking at. I try to make sense of this to my classes by telling them that taking a history of economic thought course is much like traveling: Just as the latter makes one aware of one's own cultural biases, the former help can make one aware of one's disciplinary biases. ${ }^{21}$

A related advantage is a very pragmatic one. In their research economists typically write for other economists. But in their day to day lives, particularly for those who work in liberal arts colleges or in policy settings, they often must communicate with non-economists. Economists, though, are notoriously bad at conversing with non-economists, and their graduate training does not help in this. A history of economic thought class, on the other hand, is one of the few places in the economics curriculum where economists must learn to connect economics to other disciplines within the social sciences and the humanities. Thus there is an instrumental value for economists becoming more liberally educated, if we hope to be understood and taken seriously by others outside of our field.

\footnotetext{
${ }^{20}$ A colleague in political science at Duke has recently published a book that examines a key economic concept, incentives, from an ethical standpoint. She argues that incentives may be viewed as a form of power, and as such they can be subject to abuse. A typical dilemma: What is gained and what lost if we were to incentivize our children to earn better grades by paying them? See Grant 2011.

${ }^{21}$ Of course, some tourists find travel frustrating: think of the stereotypical "ugly American" tourist who constantly complains about the strange toilets and food. I leave it to the reader to complete the disciplinary analogy.
} 
I recently taught in a summer school program that included graduate students in fields

like anthropology and history as well as economics. In terms of their knowledge of the

foundational texts of economics, the others ran rings around the economics graduate students,

who were suitably and appropriately embarrassed. To the extent that economists, in

interdisciplinary settings in the academy or in the policy arena, interact with people from other

fields, it adds credibility to what we say if we can escape the stereotype of the economist - a

smart, often arrogant, mathematically sophisticated but historically ignorant, narrowly-trained

and -focused mandarin. ${ }^{22}$

I can mention quickly that in some fields a knowledge of the history of economics can

directly benefit economists in their research. If one is a development economist, for example,

one must be sensitive to the cultural, political, juridical, economic, and social institutions that

exist in the area under study. Institutions develop over time, which is only to say that they have

histories, and there are typically also accompanying narratives that justify the constellation of

institutions that exist. Understanding such narratives provides a window into the differential

development of countries. It should perhaps come as no surprise, then, that certain Russian

and Chinese economists have recently become very interested in the writings of the

\footnotetext{
${ }^{22}$ One group that held this view of economists described the profession as suffering from a sort of disciplinary autism, and called for a new, post-autistic economics. The heterodox PAE movement has since morphed into the Real World Economics group. See http://www.paecon.net/PAEReview/. Last accessed 12/04/2012.
} 
mercantilists and of their $19^{\text {th }}$ century defenders in the German Historical School, narratives that support protectionist policies. At last year's meeting Timur Kuran offered a description of how certain key institutions, grounded in Islamic law, worked to block the development of democratic political institutions in the Middle East (Kuran 2012). Economists interested in exploring monetary reform might do well to review the writings of the Bellagio Group, a group of economists led by Fritz Machlup, Willie Fellner, and Robert Triffin who in meetings from 1964 through 1977 attempted to identify the principles that connected geopolitical, currency, business and social issues during that period, writings now being collected (Connell 2013). This group was the direct precursor to the Group of 30, led by Paul Volcker, that formed in 1978.

A final insight that studying the history of economics provides is simply to reinforce the humility that comes with realizing that the present may not be the pinnacle of all knowledge. ${ }^{23}$ The history of our discipline is littered with examples of major schools of thought that rose to a position of dominance only to disappear from our professional memory. In the $18^{\text {th }}$ century, the French Physiocrats were known throughout Europe as the foremost economists of the day. When Adam Smith came to France he met the leader of the school, the physician François Quesnay, and would have dedicated The Wealth of Nations to him had Quesnay not died before

\footnotetext{
${ }^{23}$ For the argument that widespread acceptance of and dependence on a specific set of recently developed models helped to create the systemic risk that had such dire consequences for the world economy, see Bronk 2012.
} 
its publication. Who except historians of thought now remember Quesnay's model of the circular flow, based on the circulation of the blood and captured in his Tableau Économique, which was hailed at the time by the Marquis de Mirabeau as one of the three great inventions of mankind, the other two being writing and money (see, e.g., Smith [1776] 1981, p. 679)? A bit more than a century later there was a similar phenomenon, as scores of American and European scholars flocked to the great universities of the German Empire to learn from the German Historical School economists, whose views went into rapid decline following the First World War and were dormant until the recent flurry of interest noted earlier. The fascination with general equilibrium theory mentioned above is presumably another example.

Now a lesson that one might draw from this history is that everything is as it should be, that in the science of economics there is a steady accumulation of knowledge - the schools mentioned having rightly been consigned to the dustbin of history because their doctrines have been proven wrong. But clearly another lesson, and indeed the opposite one, might be drawn, namely, that the "economic knowledge" or dominant approaches of today, like those of yesteryear, may be revealed as, well, fads. I should also point out that all three of the systems mentioned above were in their time defended as being not a, but the, "truly scientific" way to understand economic phenomena. Humility, but also a curiosity about alternative approaches, seems the wisest council here. 


\section{Hayek Understood the Dangers of Positivism}

I have argued that though the study of the history of economics has many benefits, it has disappeared in many places, and that this has occurred at least in part because of the adverse effects of a specific vision of science, one embraced by many economists, that demeaned the importance of history. ${ }^{24}$ Of course, when you ask economists why they might be content to let the history of their discipline fade away, they don't answer, "Because I have bought into the positivist rhetoric, of course!"

What do economists say? Some avail themselves of the always convenient answer that the history of economics fails to meet some sort of "market test." But let us be clear: There is no free market of ideas here. Professors determine what courses to supply, and that determines what students can demand. We offer history of economics at Duke, and those classes always fill immediately and the professors who teach them receive some of the best student evaluations in the department, even though the writing requirements are viewed by many students as onerous. If you offer it, they will come. But economics departments do not offer it. And when students ask them to (I have prompted students from other universities to demand a course in the history of economics at their own institutions) they are invariably told

- but we have no one to teach it. Catch-22.

\footnotetext{
${ }^{24}$ For additional possible causes, see the references noted in Caldwell 2004, p. 371, note 1.
} 
To be fair, the most common answer invokes opportunity cost - if one offers the history of economics, the opportunity cost is the loss of a class, or professor, in another field. And I submit to you, this argument only makes sense if one buys the implicit positivist assumption that history is unimportant because of the cumulative progressive nature of science. To which I reply: read Thomas Kuhn on paradigm shifts, or Friedrich Hayek on the dangers of scientism.

Hayek of course knew all about positivism: he grew up in Vienna, kept tabs on the meetings of the Vienna Circle of Logical Positivists, and even briefly thought about joining them, but in time turned against their ideas. Hayek also understood the importance of ideas, of intellectual history, and of the dangers when bad ideas are widely accepted. When he attacked scientism, it was with the positivists in mind. For Hayek, "scientistic" doctrines (the adjective was a pejorative for him) claimed the mantle of science, but were in reality unscientific. Hayek thought that economics is a science, but it is one that studies complex phenomena. Such sciences will never be able to do better than to make broad pattern predictions, or to provide explanations of the principle by which a phenomenon occurs. Now if this is true, then we will never be able to reach the goals laid out by the positivist view of science. If Hayek was right, economics can progress as a science, but the type of progress that can be made is quite different from what is envisaged by those in the thrall of positivism. 
In short, Hayek raised important methodological objections to the scientistic worldview, a view that is uniquely inappropriate if one is trying to understand complex phenomena. As noted above, philosophers of science have also rejected positivism. It is time for the economics profession to complete its own forsaking of this doctrine, by reintroducing the history of economics into the economics curriculum.

A Future Filled with HOPE?

I will conclude on an optimistic note, by sharing some news about what we are doing at our Center at Duke. ${ }^{25}$ The mission of the Center for the History of Political Economy is to promote research in, and the teaching of, the history of economics. We have a number of programs for doing this, among them a fellowship program for visiting scholars, and a summer in the archives program, where budding historians of economics work under the supervision of a professional archivist in organizing and cataloging our growing collection of (mostly $20^{\text {th }}$ century) economists' papers, including those of the American Economic Association and (at last count) eleven Nobel laureates.

The program of most direct relevance, however, is our summer institute. We have run three so far and anticipate running one every summer. The institutes are aimed at economists,

\footnotetext{
${ }^{25}$ The Center website is http://hope.econ.duke.edu. HOPE as an acronym stands for the History of Political Economy.
} 
sometimes graduate students, other times existing faculty members, who want to learn more about the history of economics. The summer programs for graduate students have been wildly successful; last summer we had 160 applicants for 30 or so slots, and as a result we had students from some of the best PhD programs in the country, including Yale, Penn, Brown, Northwestern, Berkeley, Minnesota, Michigan State and, I am happy to say, southern schools like Virginia, North Carolina, N. C. State, George Mason, and the University of South Florida. Duke is not alone. In fall 2012 the Economics Department at Harvard, in response to student requests, offered a history of economics to its PhD students; forty of them signed up. As I said, if you supply it, they will come.

We are hoping that the students who come through these programs will be turned on to the history of economics, that some of them will go on to offer courses in it, and still others may decide to try their hand at research. Through our website and though our fellowship program we will provide support for those who have additional interest.

The Duke Center, I will add, has gotten financial support from a variety of sources, from the Institute for New Economic Thinking, founded by George Soros, to the Earhart and Pope Foundations, to the federal government by way of the National Institute for the Humanities. 
Many people apparently long for the day that economists start to reintegrate history into the training of new economists.

What I will ask of you, fellow economists, is that if you are a graduate student or junior faculty member, you might consider coming to one of our institutes; you will be joining a growing group of economists who want to know more about the history of their discipline. And if you are a member of a faculty search committee, when you interview these excellent students for jobs in your departments, and they mention that they have studied history of economics and might like to teach a course in it or maybe even write a paper or two, that you not look at them as if they were from Mars. This is a movement with legs, and those who are joining it are, in my humble opinion, the true future of the profession. 


\section{References}

Arrow, Kenneth, and Debreu, Gerard. 1954. “On the Existence of an Equilibrium for a Competitive Economy," Econometrica, vol. 22, July, pp. 265-90.

Bateman, Bradley. 2002. "Sitting on a Log with Adam Smith: The Future of the History of Economic Thought at the Liberal Arts Colleges." In E. Roy Weintraub, ed. The Future of the History of Economics, annual supplement, History of Political Economy, vol. 34, pp. 17-34. . 2006. "Keynes and Keynesianism." In Roger Backhouse and Bradley Bateman, eds. The Cambridge Companion to Keynes. Cambridge: Cambridge University Press, pp. 271-90.

Blaug, Mark. [1980] 1994. The Methodology of Economics: Or How Economists Explain. $2^{\text {nd }}$ ed. Cambridge: Cambridge University Press. 
. 2001. "No History of Ideas, Please, We're Economists," Journal of Economic

Perspectives, vol. 15, Winter, pp. 145-64.

Boulding, Kenneth. 1971. "After Samuelson, Who Needs Adam Smith?” History of Political Economy, vol. 3, Fall, pp. 225-37.

Bridgman, Percy. 1927. The Logic of Modern Physics. New York: Macmillan.

Bronk, Richard. 2010. "The Romantic Economist Addresses the Limits of Knowledge in Markets," Gresham College Lectures, http://www.gresham.ac.uk/lectures-and-events/theromantic-economist-addresses-the-limits-of-knowledge-in-markets Accessed 08/30/2012

Buchanan, James. 1988. "Political Economy: !957-1982." In Ideas, Their Origins, and Their Consequences: Lectures to Commemorate the Life and Work of G. Warren Nutter. Washington, DC: American Enterprise Institute, pp. 115-30. 
Caldwell, Bruce. [1982] 1994. Beyond Positivism: Economic Methodology in the Twentieth Century. $2^{\text {nd }}$ ed. London: Routledge.

2004. Hayek's Challenge: An Intellectual Biography of F. A. Hayek. Chicago: University of Chicago Press.

. 2006. "The Chicago School, Hayek, and Neoliberalism." In Robert Van Horn, Philip

Mirowski, and Thomas A. Stapleford, Building Chicago Economics: New Perspectives on the History of America's Most Powerful Economics Program. Cambridge: Cambridge University Press, pp. 301-34.

Connell, Carol. 2013. Reforming the World Monetary System: Fritz Machlup and the Bellagio Group. London: Pickering and Chatto.

Davis, John. Forthcoming. "Mark Blaug on the Historiography of Economics." Manuscript.

Fisher, Franklin. 1989. "Games Economists Play: A Noncooperative View," The Rand Journal of Economics, vol. 20, spring 1989, pp. 113-24. 
Friedman, Milton. 1953. "The Methodology of Positive Economics." In Milton Friedman, ed. Essays in Positive Economics. Chicago: University of Chicago Press, pp. 3-43. . 1991. "Old Wine in New Bottles," The Economic Journal, vol. 101, January, pp. 33-40.

Frydman, Roman, and Goldberg, Michael D. 2011. Beyond Mechanical Markets: Asset Price Swings, Risk, and the Role of the State. Princeton: Princeton University Press.

Grant, Ruth. 2011. Strings Attached: Untangling the Ethics of Incentives. Princeton: Princeton University Press.

Hands, Wade. 2001. Reflection without Rules: Economic Methodology and Contemporary Science Theory. Cambridge: Cambridge University Press.

Hume, David. [1742] 1987. "Of the Rise and Progress of the Arts and Sciences." In Eugene Miller, ed. Essays Moral, Political, and Literary. Revised edition. Indianapolis: Liberty Fund, pp. 111-37. 
Keynes, John Maynard. 1936. The General Theory of Employment, Interest, and Money. New York: Harcourt, Brace and Co.

Krugman, Paul. 2009. “How Did Economists Get It So Wrong?” New York Times Magazine, September 6 .

Kuhn, Thomas. [1962] 1970. The Structure of Scientific Revolutions. $2^{\text {nd }}$ ed., enlarged. Chicago: University of Chicago Press.

Kuran, Timur. 2012. "The Economic Roots of Political Underdevelopment in the Middle East: A Historical Perspective," Southern Economic Journal, vol. 78, April, pp. 1087-95.

Lakatos, Imre. 1970. "Falsification and the Methodology of Scientific Research Programmes." In Imre Lakatos and Alan Musgrave, eds. Criticism and the Growth of Knowledge. Cambridge: Cambridge University Press. 
. 1971. "History of Science and Its Rational Reconstructions." In R. C. Buck and K. S.

Cohen, eds. Boston Studies in the Philosophy of Science, vol. 8. Dordrecht, Holland: D. Reidel, pp. 91-136.

Latsis, Spiro, ed. 1976. Method and Appraisal in Economics. Cambridge: Cambridge University Press.

Maas, Harro, and Svorencik, Andrej, eds. 2012. Witness Seminar on the Emergence and History of Experimental Economics. Manuscript.

Marx, Karl. [1847] n.d. The Poverty of Philosophy. Moscow: Foreign Languages Publishing House.

Marx, Karl and Engels, Friedrich. [1848] 1978. The Manifesto of the Communist Party. In Robert Tucker, ed. The Marx-Engels Reader. $2^{\text {nd }}$ ed. New York: Norton.

O’Brien, D. P. 2000. "History of Economic Thought as an Intellectual Discipline." In Antoin E. Murphy and Renee Prendergast, eds. Contributions to the History of Economic Thought: Essays in Honour of R. D. C. Black. London: Routledge, pp. 31-54. 
Samuelson, Paul. [1947] 1965. The Foundations of Economic Analysis. New York: Atheneum.

Smith, Adam. [1776] 1981. An Inquiry into the Nature and Causes of the Wealth of Nations. Vol. 2. Indianapolis: Liberty Classics.

Van Horn, Rob, and Philip Mirowski. 2009. "The Rise of the Chicago School of Economics and the Birth of Neoliberalism." In Philip Mirowski and Dieter Plehwe, eds. The Road from Mont Pelerin: The Making of the Neoliberal Thought Collective. Cambridge: Harvard University Press, pp. $139-78$.

Vaughn, Karen. 1993. "Why Teach the History of Economics," Journal of the History of Economic Thought, vol. 15, Fall, pp. 174-83.

Viner, Jacob. [1963] 1991. "The Economist in History." In Douglas Irwin, ed. Essays on the Intellectual History of Economics. Princeton: Princeton University Press, pp. 226-47. 
Weintraub, E. Roy. 1988. "The Neo-Walrasian Program is Empirically Progressive." In Neil De Marchi, ed. The Popperian Legacy in Economics. Cambridge: Cambridge University Press. ed. 2002. The Future of the History of Economics, Annual Supplement to Volume 34, History of Political Economy. Durham and London: Duke University Press.

Weintraub, E. Roy, and Ted Gayer. 2002. “Equilibrium Proof-Making." In E. Roy Weintraub, How Economics Became a Mathematical Science. Durham, N. C. and London: Duke University Press, pp. 183-207. 